\title{
Afet Sakınımında Özel Gereksinimli Bireyler için Geliştirilecek Mekansal Planlama İlkeleri
}

\author{
Ezgi ORHAN ${ }^{1}$ ve H.Çağatay KESKINOK ${ }^{2}$
}

\section{Öz}

Bu çalışma, sosyal yapı içindeki kırılgan grupların afetlere karşı dirençli kılınmasını sağlamak amacıyla mekânsal planlama ilkelerinin geliştirilmesi gereğini vurgulamaktadır. Kentsel alanda demografik, ekonomik, kültürel ve benzeri nedenlerle heterojenlik gösteren sosyal yapının afetlere karşı kırılganlık düzeyleri farklılaşmaktadır. Yazında kırılgan gruplar, kentsel alandaki yer seçimlerine, bireylerin fiziki koşullarına ve toplumsal yaşama katılma düzeylerine göre ayrışmaktadır. Kentsel alanda yer seçimlerine göre kırılganlık gösteren grupların planlama disiplini içinde risklerinin azaltılmasına yönelik genel ifadeler ve yaklaşımlar bulunmakla birlikte, fiziki koşulları ve toplumsal uzaklaşma sorunu nedeniyle kırılganlık gösteren gruplar için planlama ilkelerinin ve mekânsal kararların somut olarak nasıl geliştirileceği konusu belirsizliğini korumaktadır. Bu çalışma ile yaşılar, çocuklar, özel tıbbi intiyacı olanlar ve engelli bireylerin oluşturduğu fiziki koşulları nedeniyle kırılgan olan gruplar ile göçmenler, turistler ve evsizler gibi toplumsal uzaklığı olan kırılgan grupların dikkate alındığı genişletilmiş bir planlama çerçevesinin sunulması amaçlanmaktadır. Çalışmada, özel gereksinim gösteren kırılgan grupların afet sonrasındaki durumlarına yönelik olmaktan çok öncelikle söz konusu olan bireylerin ve/veya kesimlerin afetten sakınımları konusunda geliştirilmesi gereken mekânsal stratejiler üzerinde yoğunlaşılmaktadır.

Anahtar Kelimeler: afet sakınımı, kentsel kırılganlıklar, mekânsal planlama ve afetler, kırılgan sosyal gruplar,

\section{Spatial Planning Principles in Disaster Mitigation Targeting Individuals with Special Needs}

\begin{abstract}
This study highlights the need to develop spatial planning principles in order to increase the resilience of vulnerable groups within the social structure. The social groups that show heterogeneity in the urban area due to demographic, economic, cultural and similar reasons also differ in terms of their vulnerability against disasters. In the literature, vulnerable groups show disparities with respect to their location choices in urban areas, physical conditions of individuals and their participation in social life. Although planning discipline has general expressions and approaches for risk reduction of the groups showing vulnerability based on their location choices, the issue of developing concrete solutions in planning principles and spatial decisions remains uncertain for groups that are vulnerable due to their physical conditions and social divergence. Therefore, the aim of the study is to present a holistic planning framework that takes into account the vulnerable groups challenged by physical conditions such as elderly, children, those with special medical needs and of the disabled individuals, and the groups confronting with social distances such as migrants, tourists and homeless people. The focus of the study
\end{abstract}

\footnotetext{
${ }^{1}$ Doç.Dr., Şehir ve Bölge Planlama Bölümü, Çankaya Üniversitesi, Ankara.

2 Prof. Dr., Şehir ve Bölge Planlama Bölümü, Orta Doğu Teknik Üniversitesi, Ankara

*ilgili yazar / Corresponding author: ezgiorhan@cankaya.edu.tr

Gönderim Tarihi: 26.03.2019

Kabul Tarihi: 29.06.2019
}

Orhan, E., \& Keskinok, H. (2019). Afet Sakınımında Özel Gereksinimli Bireyler için Geliştirilecek Mekansal Planlama İlkeleri. Resilience, 3(1), 25-35. 
Afet Sakınımında Özel Gereksinimli Bireyler için Geliştirilecek Mekansal Planlama İlkeleri

Spatial Planning Principles in Disaster Mitigation Targeting Individuals with Special Needs

is on spatial strategies concerning the disaster mitigation of the vulnerable groups showing special needs, rather than dealing with the post-disaster situations of the targeted individuals and groups.

Keywords: disaster mitigation, urban vulnerability, spatial planning and disasters, vulnerable social groups

\section{GíRiş}

Kentsel alanda demografik, ekonomik, kültürel ve benzeri nedenlerle heterojenlik gösteren sosyal yapının afetlere karşı kırılganlık düzeyleri de farklılaşmaktadır. Bu değişken demografik ve sosyal peyzaj, afetlerin etkilerinin de bireylere göre farklılaşması sonucunu doğurmaktadır. Benzer şekilde, sosyal sistemlerin afetlere karşı gösterdiği dirençlilik ve önlem geliştirme politikaları da değişkenlik göstermektedir. Özellikle, temelde yerel olaylar olan afetler (Quarantelli, 2003) nüfus bileşimini değiştiren ve belirleyen bir niteliğe sahip olabilir. Özellikle, afetlerin en kırılgan gruplar üzerindeki etkileri diğer gruplara göre oldukça şiddetli ve kaçınılmaz olmaktadır. Bu nedenle, kırılgan sosyal grupların afetlere karşı dirençlilik düzeyi ve afetlerden nasıl etkilenecekleri bilim insanlarının ve uygulayıcıların birlikte dikkate alması gereken temel sorun alanlarından biri haline gelmektedir. Bu kapsamda, bu grupların kentsel alanda yer seçimi, kentsel hizmetlere erişimi ve kentsel yaşama katılımı açısından planlama disiplini içinde değerlendirilmesi gerektiğine işaret etmekteyiz. Bu grupları planlama çerçevesinde görünür kılmak, kullanıcıların kırılganlıklarına yönelik politika geliştirmek ve standartları oluşturmak adına önemlidir.

Bu çalışma, kırılgan birey ve grupların afet sakınımı için nasıl bir planlama çerçevesi sunulması gerektiği sorusu ile şekillenmektedir. Çalışmada, kırılgan grupları daha geniş kapsamıyla anlamaya imkan veren yazın taramasının yanı sıra Türkiye'deki afet planlaması çerçevesini oluşturan mevzuat ve uygulamalar derlenmiştir. Her iki kümede toplanan bilgi doğrultusunda, afet karşısında duyarlıı̆̆ daha da artan bireyler/kesimler üzerinde afet etkilerini azaltacak uzun ve orta erimli mekansal gelişme stratejilerinin geliştirilmesi gerektiği üzerinde tartışma yürütülmüştür.

\section{KENTSEL KIRILGAN GRUPLAR}

Özellikle, 1990'larda Birleşmiş Milletler'in uluslararası afet riski azaltma çalışmalarına katılması afet politikalarında dönüm noktası olmuştur ve afetler ülkelerin önündeki birer kalkınma problemi olarak görülmeye başlamıştır. Afetlere ilişkin geliştirilen bakış açısıyla afet sonrası yapılan yardım anlayışı yerini afet öncesi risk azaltma çalışmalarına bırakmıştır (Balamir ve Orhan, 2012). Böyle bir anlayışın temelinde afet öncesi planlama çalışmaları yer almaktadır. Diğer bir deyişle, sakınım kavramı planlama yazınına girecektir. Kurulmaya çalışılan bu bakış açısı, yine BM çatısı altında toplanan ve 2005 yılında yayımlanan Hyogo Deklarasyonu ile desteklenmiştir. Deklarasyonda, "Devletler, sınırları içindeki insanların ve mülklerin afetlerden koruma sorumluluğunu taşımaktadır, ve bu yüzden, mevcut kapasiteleri ve kaynaklarıyla uyumlu olarak, ulusal politikalarında afet riski azaltmaya öncelik vermeleri gerekmektedir" denilmekte ve görüş, devletlere halklarının afetler karşısında güvenliğini sağlama ve afet riski azaltma için geliştirilen politikaların, gelecekte büyük geri dönüşleri olan yatırımlar olacağı fikriyle pekiştirilmektedir (UN/ISDR, 2005, 2). Afetlere ilişkin geliştirilmiş bu bakış açısına göre, merkezi ve yerel yönetimler ya uluslararası politikaların gereği olan risk azaltma önlemlerini üstlenecek ve buna yönelik yatırımlar yaparak kentsel gelişmenin sürekliliğini sağlayacaktır; ya da afet sonrası meydana gelecek kayıpların maliyetin üstlenecek ve kentsel kalkınmanın kesintiye uğramasına neden olacaklardır. 
Kentsel kırılganlıklar, tarihsel süreçlerle oluşmuş sosyal, fiziksel, ekonomik sistemlerin potansiyel olarak zarar görme birikimleri olarak tanımlanabilir. Kentsel kırılganlıklar toplumun yapısı (sınıf, cinsiyet, yaş, dil, ırk, etnik köken, okuyazarlık, sivil toplum, haklar, politik kültür) ve tarihsel ve yapısal faktörlerle (ekonomik model, gelir dağılımı, demografik yapı, çevresel değerler, teknolojik gelişmişlik düzeyi) ilişkilendirilebilir (Bolin ve Stanford, 1998; Smith ve Petley, 2009). Kentsel kırılganlıkları artırıcı etkenler, kentsel nüfus artışı, sanayi yoğunluğu, plansız kentleşme, yetersiz kurumsal kapasiteler, bilgi ve kaynak eksikliği ve sınırı hazırlık düzeyi olarak sıralanabilir (Orhan 2016). Afetlerle birlikte, bu faktörler kentlerin maruz kalacakları etkiyi derinleştirerek, doğal tehlikeleri birer kalkınma problemine dönüştürürler. Kentlerin sürdürülebilir kalkınmasını sağlamak için kentsel kırılganlıkların azaltılması, sosyal, ekonomik, fiziksel sistemlerin güçlendirilmesi gerekmektedir. Diğer bir deyişle, kentsel dirençliliğin kazandırıması risk azaltma politikalarına ve kentsel kırılganlıkların giderilmesi için atılan adımlara bağlıdır.

Kentsel alanda tehlikeye maruz kalma potansiyeli yüksek olan gruplar, yazında, niteliklerine göre sınıflandırılmaktadır. Kırılgan sosyal gruplar hakkında öncü çalışmalara sahip olan Ben Wisner'a göre (2003), kentler, özellikle de büyük kentler sosyal açıdan büyük çeşitlilik gösteren alanlardır ve kentler, ekonomik, din, etnik köken, dil bakımından oldukça farklı gruplara ve kaçak yaşayanların oluşturduğu bir gruba ev sahipliği yapmaktadır.

Bu kapsamda, kırılgan gruplar, kentsel alandaki yer seçimlerine, bireylerin fiziki koşullarına ve toplumsal yaşama katılma düzeylerine göre ayrışmaktadır (Tablo 1). Kentsel alan kullanımı, bir diğer deyişle, mekânsal yer seçimi nedeniyle kırılgan gruplar kaçak yaşama alanlarında konumlanan ve kentsel alanın tehlikeli bölgelerini kullanan gruplardır. Fiziki koşulları nedeniyle kırılganlık gösteren gruplar güçsüz durumdaki yaşlılar, çocuklar ve bebekler, engelliler, özel tıbbi ihtiyacı olan hastalar ile zihinsel rahatsızlığı olan bireyleri kapsamaktadır. Son olarak ise, toplumsal uzaklık nedeniyle kırılganlık gösteren grupları evsizler, göçmenler ve turistler olarak sınıflandırmak mümkündür.

Tablo 1. Kırılgan sosyal gruplar

\begin{tabular}{|l|cl|}
\hline Kırılgan gruplar & Özel gereksinimli bireyler \\
\hline Mekânsal yer seçimi nedeniyle & - & Gecekondu alanında yaşayanlar \\
kırılganlık gösteren gruplar & - & Derin vadi, elverişsiz yamaçlarda yaşayanlar \\
& - & Eski maden ocakları üzerinde yaşayanlar \\
& - & Dere yatakları, taşkın sahaları üzerinde yaşayanlar \\
& - & Tehlikeli sanayi yakınlarında yaşayanlar \\
\hline Fiziki koşulları nedeniyle & - & Yaşlılar \\
kırılganlık gösteren gruplar & - & Çocuklar ve bebekler \\
& - & Engelliler \\
& - & Özel tıbbi intiyacı olanlar \\
& - & Zihinsel rahatsızlığı olanlar \\
& & \\
\hline Toplumsal uzaklık nedeniyle & - & Evsizler \\
kırılganlık gösteren gruplar & - & Göçmenler \\
& - & Turistler \\
& & \\
\hline
\end{tabular}




\section{PLANLAMA ÇERÇEVESININ ÖZEL GEREKSINIMLI BIREYLERE BAKIŞ AÇISI}

Kırılgan sosyal grupları kentsel alanda yer seçimi, kentsel hizmetlere erişimi ve kentsel yaşama katılımı açısından planlama disiplini içinde değerlendirmek gereklidir (Tablo 2). Kentsel alanda yer seçimlerine göre kırılganlık gösteren grupların planlama disiplini içinde risklerinin azaltılmasına yönelik mekânsal politikalar geliştirilmekte ve uygulamalar yapılmaktadır. Bu uygulamaların başında kentsel dönüşüm ve kentsel sağlıklaştırma gelmektedir. Mekânsal politika ve uygulamaların amacı altyapı, sosyal donatı ve konut niteliği bakımından çöküntü alanı haline gelmiş bölgelerde yenileme yoluyla yaşam kalitesini artırmak ve kentsel güvenliği sağlamaktır.

Ancak, özellikle, fiziki koşulları ve toplumsal uzaklaşma sorunu nedeniyle kırılganlık gösteren gruplar için planlama ilkelerinin ve mekânsal kararların geliştirilmesi gereği ortaya çıkmaktadır. Bu grupların temel sorun alanları kentsel hizmetlere erişim ve kentsel yaşama katılım yönünden olmaktadır. Fiziki koşullar nedeniyle özel gereksinim gösteren bireyler için sağlık, erişim ve özel bakım konularında afet durumunda sorunların yaşanmasını en aza indirecek politikalara gereksinim duyulmaktadır. Toplumsal uzaklığı nedeniyle kırılganlık gösteren gruplarda ise temel sorun alanını iletişim, barınma ve erişim konuları oluşturmaktadır.

Tablo 2. Kırılgan sosyal gruplara yönelik önlem alanları ve mekânsal politikalar

\begin{tabular}{|c|c|c|}
\hline Kırılgan gruplar & Temel Sorun Alanları & Önlem Politikaları \\
\hline $\begin{array}{l}\text { Mekânsal yer seçimi } \\
\text { nedeniyle kırılganlık } \\
\text { gösteren gruplar }\end{array}$ & $\begin{array}{l}\text { - Barınma } \\
\text { - Yoksulluğu azaltma }\end{array}$ & $\begin{array}{l}\text {-Kentsel dönüşüm } \\
\text {-Kentsel sağlıklaştırma ve yenileme }\end{array}$ \\
\hline $\begin{array}{l}\text { Fiziki koşulları } \\
\text { nedeniyle kırılganlık } \\
\text { gösteren gruplar }\end{array}$ & $\begin{array}{l}\text { - Sağlık } \\
\text { - Erişim } \\
\text { - Özel bakım }\end{array}$ & $\begin{array}{l}\text { - Erişilebilirlik ana konuları } \\
\text { - Standartlar } \\
\text { - Tasarım ilkeleri } \\
\text { - Kentsel arazi kullanımları } \\
\text { - Toplum katılımı }\end{array}$ \\
\hline $\begin{array}{l}\text { Toplumsal uzaklık } \\
\text { nedeniyle kırılganlık } \\
\text { gösteren gruplar }\end{array}$ & $\begin{array}{l}\text { - İletişim } \\
\text { - Erişim } \\
\text { - Barınma }\end{array}$ & $\begin{array}{l}\text { - Sektörel kararlar } \\
\text { - Yerel yedekleme kapasitesi } \\
\text { - Kamusal alanda bilgilendirme }\end{array}$ \\
\hline
\end{tabular}

Çalışmada geniş anlamıyla tanımlanan kırılgan grupların afet risklerini en aza indirecek mekânsal politikalar kentsel alanda yer seçim, kentsel hizmetlere erişim ve kentsel yaşama katıım açılarından ortaya konulmuştur. Kırılgan grupların afet yönetimi politikalarının oluştururken ortaya konulan bu üç ayaklı yaklaşım yönetsel, mekânsal ve toplumsal boyutları olan politika çerçevesinin odaklarını oluşturmaktadır (Şekil 1). 


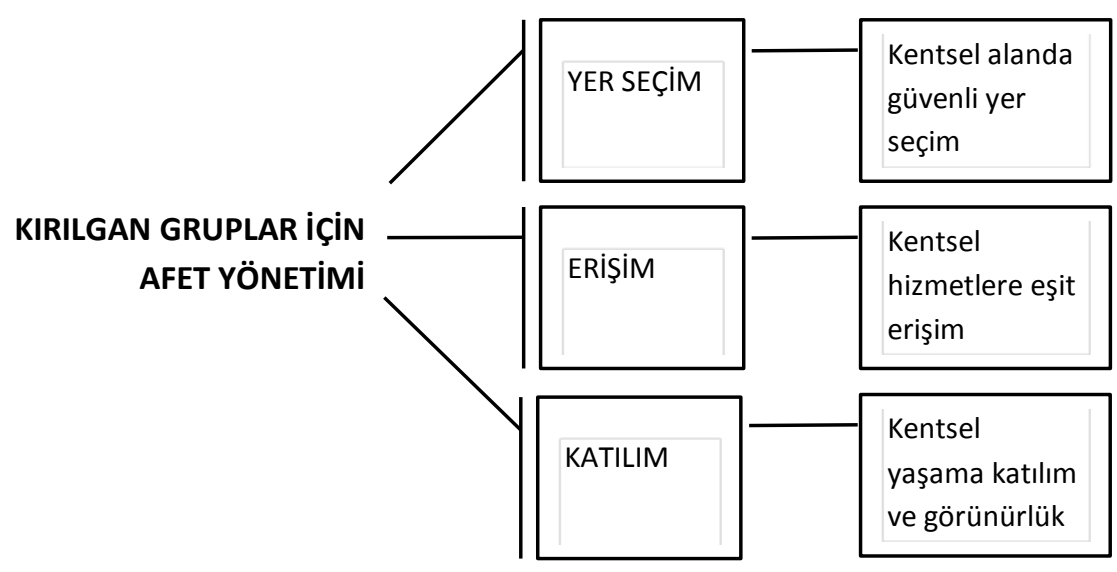

Şekil 1. Kırılgan gruplar için afet yönetimi odakları

\subsection{Yönetsel yaklaşım}

Afet yönetimi konusunda yerel halkın güvenliği hem valinin, hem de belediyenin idaresi altındadır. Afet konusunda, ülke politikasının yereldeki uygulayıcısı validir. Vali, devletin yerel teşkilatıyla beraber, il düzeyinde acil durum yönetiminden, kaynakların kullanımından ve kentsel güvenliğin sağlanmasından sorumludur. Diğer yandan, seçilmiş bir organ olan yerel yönetimler yerleşimlerin, toplumun ve kaynakların yönetimiyle ilgili yetki ve sorumlulukları vardır. Buna ek olarak, sivil toplum kuruluşları faaliyetlerini yerel düzeyde yürütürler ve kentsel kırılgan gruplar hakkında çalışmalar yapabilirler. Wisner (2003)'a göre, belediyeler toplumu doğal tehlikelerden korumak ve kırılgan grupların kendilerini koruma kapasitelerini geliştirmelerine yardımcı olmak için gerekli olan teknik uzmanlık ve parasal kaynaklara sahiptir; ancak belediyeler zarar görebilir olan bu gruplar hakkında ayrıntılı bilgiye ve bu grupların güvenine sahip olamayabilir. Öte yandan aynı çalışmanın STK'lar hakkında öne sürdüğü yargı, kırılgan gruplar hakkında ayrıntılı bilgiye sahip oldukları ancak yeterli finansal ve teknik kaynaklarının bulunmadığı yönündedir (Wisner, 2003).

Afet yönetimi bakımından kentlerde mekân düzenlemesi, standartları ve kullanımı konularında doğrudan yerel halkın ihtiyacını anlamaya yönelik ara kademe yerel örgütlenme birimlerine, bu birimlerin işleyişinde katılımcılık esaslarının belirlenmesine intiyaç vardır.

Afet yönetiminde özel gereksinimli bireyler hakkında politika geliştirme intiyacı bu tür bir örgütlülüğün kurulmasında fırsatlar sunabilir. Geniş anlamıyla kırılgan grupların gereksinimlerinin ortaya konulacağı ortak platformlar, sürdürülebilir alan yönetiminin oluşmasına katkı verebilirler. Bu platformların, yerel yönetimlerin, sivil toplumun, araştırmacıların ve medyanın birlikteliği ile yerel kırılgan gruplara ve yere özgü sorunları belirlemesi ve tartışmaya açması çok boyutlu bir afet yönetimi yaklaşımının oluşmasına ve güncel kalmasına imkân verecektir.

\subsection{Mekânsal politikalar}

Türkiye kentleşme pratiği özellikle 1950'lerden bu yana disiplin altında tutulmakta zorlanılan ve hızlı artan nüfusu barındırmaya çalışırken bu süreçte ortaya çıkan sorunlarla yüzleşmekte olan bir seyir izlemektedir. Kentsel alan üzerindeki en büyük tehditlerden birini yüksek çeşitlilik 
gösteren afetler oluşturmaktadır. Afet riski altındaki yerleşimlerin heterojen sosyal gruplar üzerinde oluşturacağı tehditlere yönelik politika üretme ihtiyacı karar vericiler ve uygulayıcıların göz önüne alması gereken başlıca konulardan biridir. Doğal tehditlerin bulunduğu alanlarda niteliksiz yapılaşmayla birlikte başlayan süreç kentsel alanların uygunsuz kent-içi yer seçimi, imar, yapılaşma ve kullanım tercihleri ile risklerini artırmaktadır (Balamir, 2014). Kırılgan grupların afet yönetiminin bir parçası haline gelmesi ve bu grupların kırılganlıklarını azaltacak mekânsal politikaların geliştirilmesi hayati önem taşımaktadır.

Mekânsal yer seçimleri nedeniyle kırılgan olan gruplara yönelik 5393 sayılı Belediye Kanunu'nun Dönüşüm/Gelişim konulu 73. Maddesi, 5104 sayılı Kuzey Ankara Girişi Kentsel Dönüşüm Projesi Kanunu, 6306 sayılı Afet Riski Altındaki Yerleşimlerin Dönüştürülmesine Yönelik Kanun ile 5366 sayılı Yıpranan Tarihi ve Kültürel Taşınmaz Varlıkların Yenilerek Korunması ve Yaşatılarak Kullanılması Kanunu kentsel yenileme ve dönüşüm yoluyla afet risklerini azaltılması hedeflenmiştir.

Afet yönetiminde fiziki koşulları nedeniyle kırılgan bireyler için kentsel ölçekte uygulanacak önlemlerin ise planlamanın hangi araçlarıyla geliştirilmesi gerektiği konusu üzerinde henüz tartışılmamış yeni bir alan olarak ortaya çıkmıştır. Bu ise, "kent planlaması ve kentlerin tasarımı ile ilişkili temel ilkeler ve kavramlar ile afet planlamasının temel kavramlarının nasıl uzlaştırılacağı ve ortak çerçevenin nasıl geliştirileceği” sorusu ile ilişkilidir (Keskinok, 2014, 6). Afet riskli kentlerde kırılgan grupların ihtiyacını gözetirken, afet yönetimi aşamalarında dikkate alınacak ölçüler, standartlar ve biçimler ile yapılaşma düzenleri nasıl olmalıdır konusu tartışmaya değerdir.

Fiziki koşullarıyla nedeniyle kırılgan gruplara yönelik mekânsal ilkelerin imar mevzuatında nasıl yer alması gerektiği üzerine düşünülmelidir. Bu sayede, kente ve kent parçasına özgü koşulların dikkate alındığı imar planlarında kentsel alan kullanımları ile standartlar geliştirilerek bu grupların afet risklerini en aza indirecek politikalar geliştirmek olasıdır (Şekil 2).

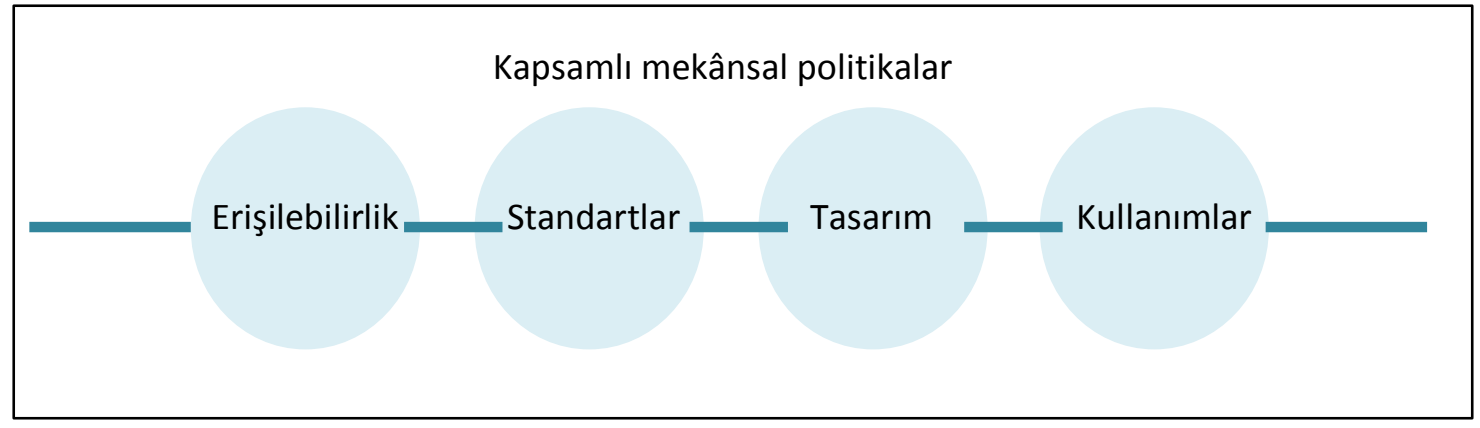

Şekil 2. Kentsel mekânsal planlama ilkeleri

Ancak, imar mevzuatı ve imar planları homojen bir toplumsal yapının içinde sağlıklı bireyler kabulü/varsayımı üzerinden kurulan bir düzenlemeyi işaret etmektedir. Kentsel alan kullanımları, hizmetlere erişim ve kentsel standart ve ölçülerin oluşturulması hareket olanaklarının sınırlıl̆̆ı olan bireylere göre farklı bir yorumlama ihtiyacı doğurmaktadır. Bu halde, temelde sosyo- 
ekonomik nedenlerle homojen olmayan bir toplumsal yapıda kamu yararını arayan planlama ilkeleri fiziki koşulları nedeniyle heterojenlik taşıyan sosyal gruplara nasıl yaklaşmaktadır, ya da yaklaşmalı mıdır? Planlama, tabi olduğu mevzuatın asli gereği olarak bireylere eşitlik perspektifinden yaklaşmakta ve standartlarını oluştururken tekil bir -sağlıklı- birey kabulü üzerinden mekânsal kararlarını oluşturmaktadır. Bu varsayım, homojen ve kırılganlıkları olmayan bir toplumsal yapı üzerine inşa edildiğinden ve toplumun farklılaşmasını temsil etmede noksan kaldığından acil durum koşulları için planlama çerçevesinin geliştirmesi gereği yeniden ortaya çıkmıştır. Bahsi geçen gereklilik doğrultusunda planlamada yeni bir tartışma alanı açacak sorun alanları aşağıdaki gibi oluşmuştur;

- Kırılganlık durumlarına göre erişilebilirlik sorunları ve haritası çıkarılabilir mi? Bu tüm planlama çalışmalarının ön hazırlık/araştırma aşamasında üretilmesi gereken bir çalışmaya dönüştürülebilir mi? Yani plan araştırma raporlarının kapsamak zorunda olduğu konular arasına sokulabilir mi?

- Kırılganlıklar açısından öncelik taşıyan kesimler için standartlar yeniden belirlenebilir mi? Ya da yasal çerçevede/yönetmeliklerde öngörülen standartların planlama çalışmalarında kırılganlık koşullarına göre yeniden değerlendirilmesi öngörülebilir mi?

- Tasarım ilkelerinde kırılgan gruplara göre farklılaşma gerekli midir?

- Kentsel alan kullanımlarının dağılımının belirlenmesinde, acil durum şartlarında kırılgan grupların ihtiyaçlarının karşılanması problemi öncelikli sorun haline getirilebilir mi?

Bu sorular aynı zamanda imar mevzuatı içerisine özel gereksinimli bireylerin nasıl katılacağına yönelik ortaya atılan sorulardır ve yanıtlanması kırılgan grupları dikkate alan bir bakış açısıyla imar mevzuatını desteklenmesiyle mümkün olacaktır. Bu sorular ışığında, imar planı çalışmalarına yön verecek özel gereksinimli bireylere dair konular erişilebilirlik, standartlar, tasarım ve kullanımlar başlıkları altında ele alınmıştır;

- Erişilebilirlik: Kentsel mekânın kullanımının tüm bireylerin erişimine imkân verecek bir tasarım yaklaşımıyla üretilmesi intiyacı bulunmaktadır. Erişilebilirlik kavramının yapı ve açık alanlara erişim, ulaşım ve altyapıya, hizmetlere ve bilgiye erişimin her kademede sağlanması gerekliliği göz önünde bulundurularak geniş anlamda düşünülmesi gerekmektedir.

- Standartlar: Başta sağlık tesisleri olmak üzere, yerleşim birimleri içinde yer alan sosyal donatı standartlarının afet riski yüksek olan bölgelerde yeniden düşünülmesi gereklidir. Buna göre, sağlık kademelenmesinin ilk ayakları olan sağlık ocakları ve aile hekimlikleri, kentlilerin gündelik intiyacını karşılayacak ticaret merkezleri mahalle birimindeki yerleşimlerde hizmet vermeli ve bunların kapsadığı alan yürüme mesafesi içinde yer almalıdır. Tüm sosyal donatıların yaya ve araç yollarıyla ulaşılabilir ve toplu taşım duraklarıyla desteklenmiş olması gereklidir. Benzer şekilde, kentsel açık alanların hizmet edilen nüfus büyüklüğüne göre geniş tutulması ve mümkünse donatılar arasında sürekliliği olan bir biçimde korunması ve planlanması önerilmektedir. Özellikle yoğun yapılaşmış kentlerde afet risklerini azaltmak için kentsel açık alanların korunması ve bu alanların gerektiğinde afet merkezleri olarak kullanılması göz önüne alınmalıdır. Acil 
durum koşullarında bu alanlar değişimli kullanım potansiyeli sunmakta ve geçici barınma, toplanma, dağıtım, geçici depolama amacıyla kullanılabilir.

- Tasarım: Kentsel yapılı çevrenin tasarımının kırılgan grupların kullanımına uygun hale getirilmesi önemlidir. Bunun için evrensel tasarım ilkelerinin benimsendiği yapıların ve açık alanların tüm kullanıcı türlerine olanak verir hale gelmesi gereklidir. Tüm sosyal donatıların ve kamusal alanların tasarımında özellikle acil durumda erişimi kolaylaştıracak biçimde düzenlemeler yapılması bir zorunluluktur. Yapı girişlerinin sokak ile ilişkileri, sokak ve kaldırım genişlikleri, yol-otopark bağlantıları, yol ağının hiyerarşik düzende oluşu, ada ve parsel büyüklükleri, yapı biçimleri ve yükseklikleri, yaya dolaşımı kentsel doku ve tasarımdan kaynaklı riskleri en aza indirmek için ilgili plan ölçeğinde karar üretilebilecek konulardır (Balamir, 2007). Bu noktalarda yapılan özel gereksinimli bireylerin intiyacına yönelik tasarımlar tahliye ve erişme kolaylıkları sağlayabilecektir. Kentsel dokuda uygulanacak kırılgan gruplara duyarlı tasarım anlayışı farklı topografik nitelikler taşıyan alanlarda çeşitlilik gösterebilir; özellikle eğimli alanlarda kurulan yerleşimlerde meydana gelebilecek afet türlerinde yapılaşma şartlarının ve dokuya ilişkin standartların plan notlarında tarif edilmesi gereklidir.

Kırılgan grupların erişiminde özel taşıtların yanı sıra toplu taşıma olanaklarının geliştirilmesi ve çeşitlendirilmesi için politikalar üretilmelidir. Yaya geçitleri, kaldırımlar, alt ve üst geçitlerin evrensel tasarım ilkelerine göre tasarlanması, işaretlenmesi, aydınlatılması, beraberinde kullanıcı güvenliğini getirecektir. Özellikle toplu taşım durakları araç türüne, hizmet frekansına, yüzey türüne göre tasarlanmalı, yolcu yoğunluğuna uygun platform genişliği belirlenmeli ve kullanıcı dostu geçişler oluşturulmalıdır. Durak tasarımlarında uygulanacak standartlar acil durumlarda özel gereksinimli bireylerin tahliyesini kolaylaştıracağından bu alanların tüm kullanıcı gruplarını dikkate alması gerekmektedir. Fiziki koşulları nedeniyle kırılgan grupların acil durum erişimi düşünüldüğünde, durakların erişimini zorlaştırıcı yer altı ve üstü konumlarından kaçınarak yüzeyde çözülmesine olanak verilmelidir. Özellikle, yoğun kent merkezlerinde yer altı durakların erişilebilirliğini artırıcı rampa benzeri mekanik olmayan çözümler ve ögelerle desteklenmesi gereklidir.

- Kullanımlar: Kentsel arazi kullanımlarının hizmet düzeyine göre uygun ölçeklerde belirlenmesi temel planlama ilkelerinden biridir. Bu nedenle, komşuluk ve mahalle biriminden başlayarak, kentsel hizmet ve donatıların yer seçimlerinin yapılması, bu kullanımların kentsel nüfus büyüklüğü ve yoğunluğuna göre dengeli dağıtılması, kırılgan grupların yığıldığı alanlarda özellikle sosyal donatı ve kamusal kullanımları adil biçimde konumlanması esasları planlarda belirlenmelidir.

Kullanım türlerinin belirlenmesinde kullanımlar arası uygunluğa dikkat edilmeli ve özellikle kırılgan grupların yaşam alanlarında risk artırıcı unsurları barındıran kullanımlardan kaçınılmalıdır (Orhan, 2018). Yanıcı, patlayıcı, kirletici içeriğe sahip kullanımlar, benzinlikler, yüksek gerilim hatları, istasyon ve depolar barındırdığı riskler nedeniyle yaşam çevrelerinden uzakta ve güvenlik tedbirleri tasarlanarak yerleştirilmelidir. 


\subsection{Risk iletişimi}

Toplumsal özellikleri nedeniyle kırılgan olan grupların afet risklerini azaltmak için geliştirilmesi gereken mekânsal önerilerin başında kamusal alanı erişilebilir kılmak ve bunu kolaylaştıracak bilgi hizmetlerini sunmak gelmektedir. Acil durumlara ilişkin evsizler, turistler ve göçmenlerle iletişimi sağlayacak duyuru ve bilgilendirmelerin farklı dillerde yapılması, acil durum planlarının görünür olması, tahliye kanalları hakkında bilgilendirici duyuruların özellikle kamusal alanda yer alması, bu grupların barınma intiyaçlarına yönelik yerel yönetimlerin yedeklenmiş yatak kapasitesi hazırlanması, acil durumlarda yerel halkla birlikte hareket etmeyi kolaylaştıracak tedbirler alınması, mekânsal olarak bu grupların yığıldığı alanların belirlenmesi ve acil durum görevlilerinin gerektiğinde bu alanlara ulaşmasını sağlamak gerekmektedir.

Turizm merkezlerinin belirlenmesinde doğal tehlikeleri dikkate almak, tehlikeye maruz alanlarda kitle turizmini özendirecek yatırımlardan kaçınmak, turizmin yoğunlaştığı alanlarda afet ve acil yönetim planları oluşturmak, turizm alanlarında yapılacak yapı ve tesislerde yapı kalitesi ve sağlamlığını denetleyici hizmetler sunmak, turizm sezonlarında artan kullanıcı talebinin oluşturduğu altyapı ve sosyal donatı intiyacına yanıt veren ve yedekleme kapasitesi sunan bir altyapı sunumu geliştirmek, acil durum toplanma alanlarını ve tahliye kanallarını belirlemek, turistlerin acil durumda yapması gerekenleri gösteren uyarı dokümanları hazırlamak ve dil sorunu nedeniyle başta yabancılar olmak üzere olası iletişim sorunları giderici önlemler almak turistlerin bulundukları yerdeki riskleri en aza indirgemeye yardımcı olacaktır.

\section{DEĞERLENDIRME: AFET SAKINIMI VE ÖZEL GEREKSINIMLİ BİREYLER}

Bu çalışma, sosyal yapı içindeki kırılgan grupların afetlere karşı dirençli kılınmasını sağlamak amacıyla mekânsal planlama ve tasarım ilkelerinin belirlenmesinin gerekliliğine işaret etmiştir. Bu çalışma ile riskli alanlarda yer seçerek mekânsal kırılganlık gösteren gruplar, yaşılar, çocuklar, özel tıbbi intiyacı olanlar ve engelli bireylerin oluşturduğu fiziki koşulları nedeniyle kırılgan olan gruplar ile göçmenler, turistler ve evsizler gibi toplumsal uzaklığı olan kırılgan grupların dikkate alındığı genişletilmiş bir planlama çerçevesi sunulmaktadır.

Çalışma, afetler karşısında kırılganlık koşullarını dikkate almayan, tüm kesimlerin afetler karşısında aynı koşullarda olduğunu varsayan bakış açılarına ve yerleşik yaklaşımlara bir eleştiri getirerek, afet öncesi ve sonrası için planlama ve tasarım çerçevelerinin kırılganlık ölçütüne göre yeniden düşünülmesi gerektiğini vurgulamaktadır. Bu amaçla, çalışma planlama ve tasarım ilkeleri yönünden kırılgan gruplara yönelik mekânsal kararlar geliştirilmesine dikkat çekmektedir; ileri yapılacak çalışmalarla da, bu mekânsal kararların neler olduğuna dair somut yanıtların üretilmesi ve çeşitlendirilmesini gereğini savunmaktadır. Kentlerin ve insan yerleşmelerinin tasarlanmasında ve planlanmasında, önemli olan özel gereksinimli bireyler için ayrı mekânlar değil özel gereksinimli bireylerin de yer alacakları ortak mekânı tasarlamaktır; özel gereksinimli bireyler için mekân oluşturmak yerine tüm mekânları özel gereksinimli bireyleri varsayarak tasarlamak esas olmalıdır. Afet yönetiminde kırılgan grupların dikkate alınmasına dair bir gerekliliğe işaret ederek, meydana gelebilecek her somut durumda ve olayda genel ilkesel bir yaklaşım olarak ne tür planlama ilkelerinin gözetileceğine işaret etmektedir. Mekânları tasarlarken ve planlarken, çoklu seçenekleri ve süreklilikleri geliştirmek, afet sakınımı kadar afet koşullarında başta özel gereksinimli bireyler kadar tüm insanlar için anlamlı bir tercih olacaktır.

Mekânsal, fiziksel ve toplumsal nedenlerle kırılganlık gösteren gruplar afetlere karşı dirençli olma mekanizmaları geliştirmede kısıtı kalmaktadır; bu sınırlı başa çıkabilme yetisi sosyal 
grupların afet risklerini ve afet anında ve sonrasında karşılaştıkları sorunları artırmaktadır. Bu nedenle, kırılgan gruplara yönelik geliştirilecek kapsamlı risk azaltma politikaları kentsel heterojen nüfusun afetlere karşı dirençli olmasına katkı sağlayacaktır. Çalışma, kırılgan gruplara yönelik geliştirilecek planlama ilkelerini üç odakta toplamaktadır; kentsel alanlarda yer seçimi kararları, kentsel hizmetlere erişilebilirlik ve kentsel yaşam katılım olanakları. Bu üçayak üzerinden, özel gereksinimli bireylerin afet yönetiminde gözetildiği bir planlama yaklaşımının temel ilkelerinin ortaya konulmuştur. Buna göre, yönetsel bakımından ara kademe yerel örgütlenme birimlerinin oluşturularak katılımcı bir karar verme ve uygulama mekanizmasının oluşturulması gerekir. Öte yandan, kentleşme ve imar koşullarını içeren mevzuatta kentsel kırılgan grupların yer seçimlerini düzenleyen kararların özel gereksinimli bireylerin gözetilerek yeniden ele alınması intiyacı ortaya çıkmıştır. Başta acil durumlarda olmak üzere kentsel alanlara, kamusal hizmet ve bilgiye erişim için standartların yeniden oluşturulması gerektiği açıktır. Yapılı ve açık alanların tasarımında ve arazi kullanım kararlarında yere özgü koşullar ve kırılgan grupların dikkate alınmalıdır. Yazıda bahsi geçen ilkelerin başta yoğun yapı stoku ile yapılaşmış afet riski yüksek kentlerde uygulanması beklenir. Aynı zamanda, yeni gelişim alanlarında bu bilgiler ışığında kırılgan grupların risklerine duyarlı kent parçaları üretilmelidir. Son olarak, toplumun tamamının ve kentsel yaşama katılan tüm bireylerin afet riskleri ve acil durum hakkında bilgilendirilmesi ve tüm çevrelerin risk iletişimini kolaylaştırıcı önlemler alınması gerekmektedir.

Çalışmanın kavramsal olarak ilerletilmesi için imar mevzuatının gözden geçirilmesi ve "kırılganlık" kavramının ilgili mevzuata hukuki bir kavram olarak nasıl yerleştirilebileceği üzerinde düşünmek gerekir. Diğer yandan, takip eden çalışmalarda, kırılgan grupların afetlerden nasıl etkilendiği araştırılmalı, zarar gören grupların afet sonrası intiyaçları belirlenmeli ve iyileşme süreçleri izlenmeli, bununla birlikte iyileşme sürecindeki temel sorun alanları tespit edilmelidir. Böylece, farklı nedenlerden dolayı kırılganlık gösteren grupların ayrıştırılmasına ve kırılganlık koşullarına göre yerel ve merkezi yönetimlerin afet yönetiminde somut politikalar ortaya çıkarmasına katkı sağlanabilecektir. 


\section{KAYNAKLAR}

Aksoy, Y., Turan, A. Ç., ve Samur, D. (2009) "İstanbul İli Fatih İlçesi Açık Yeşil Alanlar ve Yapılaşmanın Ekolojik Açıdan Yıpranmışlık ve Geri Dönüşüm İle İlgili Olarak Değerlendirilmesi”, Uludağ Üniversitesi Mühendislik-Mimarlık Fakültesi Dergisi, 14(2) 137-50.

Balamir, M. (2007) "Risk Yönetimi ve Yerel Yönetimler", N. Erkan, A. Güner ve K. Demeter (der.) Afet risk yönetimi: Risk azaltma ve yerel yönetimler, Marmara Üniversitesi ve Dünya Bankası: İstanbul; 27-63.

Balamir, M. (2014) Deprem Tehlikesi ve Kentsel Dönüşüm, ODTÜ Mimarlık Fakültesi Cep Kitapları, ODTÜ MF Basım İşliği: Ankara.

Balamir, M. ve Orhan, E. (2012) “Uluslararası Afet Politikaları", Melih Ersoy (ed.) Kentsel Planlama Ansiklopedik Sözlük, Ninova Yayıncılık, İstanbul, sy.457-460

Bolin, R.C. ve Stanford, L. (1998) "The Northridge Earthquake: Community-based Approaches to Unmet the Recovery Needs", Disasters, (22) 21-38.

Ersoy, M. (2009) Kentsel Planlamada Arazi Kullanım Standartları, TMMOB Şehir Plancıları Odası Yayınları: Ankara.

Keskinok, H.Ç. (2014) Planlama ve tasarım öğrencilerine afet planlaması kentsel gelişme planlama ve tasarım sorunları üzerine düşünceler ve sorular, ODTÜ Mimarlık Fakültesi Cep Kitapları, ODTÜ MF Basım İşliği: Ankara.

Orhan, E. (2016) "Reading Vulnerabilities Through Urban Planning History: An EarthquakeProne City, Adapazarı Case From Turkey", METU Journal of the Faculty of Architecture, 33(2) 239-259.

Orhan, E. (2018) "Tarihi Kent Merkezlerinin Kırılganlığı ve Afet Yönetimi Üzerine Bir Değerlendirme: Ankara Saraçlar Sokağı Yangını Örneği”, Idealkent, 9 (23) 189-215.

Quarantelli, E.L. (2003) "Urban Vulnerability to Disasters in Developing Countries: Managing Risks", A. Kreimer, M. Arnold, A. Carlin (eds), Building Safer Cities: The Future of Disaster Risk. The World Bank, Washington, DC, 211-29.

Smith, K. ve Petley, D.N. (2009) Environmental Hazards: Assessing Risk and Reducing Disaster, 5. Baskı, Routledge.

Wisner, B. (2003) "Disaster risk reduction in megacities: making the most of human and social capital", A. Kreimer, M. Arnold, A. Carlin (eds), Building safer cities: The future of disaster risk, The World Bank, Washington, DC, 181-96. 